En relación con la nota de Perissinotto mencionada al comienzo, puede notarse que el fenómeno de la asibilación -atendiendo a las realizaciones de /-r/ implosiva (en cualquier posición) y de $/ \mathrm{rr} /$ - es menos frecuente a nivel "nacional" que a nivel "capitalino", de manera que, desde un punto de vista geográfico, podría verse en la ciudad de México un foco irradiador del fenómeno; que éste se presenta más en el habla femenina que en la masculina, y más en los hablantes de los GG I y II que en los del GG III; y que, desde el punto de vista sociocultural, el nivel medio presenta el mayor grado de frecuencia.

Universidad Nacional Autónoma de México

José G. Moreno de Alba y El Colegio de México.

\title{
EL CANCIONERO ESPAÑOL (COD. REG. LAT. 1635) DE LA BIBLIOTECA VATICANA
}

Presento en estas páginas la descripción y el índice detallado de un cartapacio desconocido de la segunda mitad del siglo xvi, como anticipo de la edición íntegra que de él estoy preparando. El ms., cuidadosamente ejecutado, contiene más de 230 composiciones de todo tipo, inéditas en su mayoría. Unos 145 textos (entre ellos un nutrido e interesante grupo de romances) ni siquiera se conocen en otros mss. El gusto muy amplio del recopilador permite considerar la colección como un buen ejemplo de las preferencias temáticas y formales de la época. Es oportuno anunciar el hallazgo del nuevo cancionero en estos momentos en que, gracias a los trabajos infatigables del malogrado Antonio Rodríguez-Moñino, se ha suscitado un interés tan grande por la poesía cancioneril del Quinientos. El nuevo ms., además de enriquecer el caudal poético del período, contribuirá a la fijación de textos críticos de poemas conocidos y aclarará muchos problemas de diversa índole, como atribuciones, influencia y cronología.

Se trata del Codex Reginensis Latinus núm. 1635 de la Biblioteca Vaticana ${ }^{1}$. Formó parte, evidentemente, de los antiguos fondos de la colección Reginensis, o sea la biblioteca particular de la reina Cristina de Suecia, que se constituyó a mediados del siglo xvir y pasó a la Vaticana en 1690. Sin embargo, el catálogo de esa colección, terminado en 1691 y publicado en 1739 , no incluye nuestro ms. entre los dos mil que enumera ${ }^{2}$. Es verdad que entre 1690 y 1740 "le fonds de la Reine

1 No lo he consultado directamente, sino en el microfilm que se guarda en la colección de la Knights of Columbus Vatican Film Library, Saint Louis University.

2 El catálogo fue publicado por MontFaucon en las pp. 14-61 y 96-97 de la Bibliotheca bibliothecarum manuscriptorum nova (1739). He consultado Les manuscrits de la reine de Suède au Vatican. Réédition du catalogue de Montfaucon et. cotes actuelles, Città del Vaticano, 1964 (Studi e testi, 238) : el núm. 1560 del catálogo (hoy núm. 81) se intitula "Anonymi Hispanica carmina", pero esto es crrata por Hisperica Famina. (Véase la descripción de este ms. del siglo Ix en ANDREAS WiLMART, Codices Reginenses Latini, t. 1, Bibliotheca Vaticana, 1937, p. 179.) 
s'augmenta de beaucoup de manuscrits qui y furent déposés... pour des raisons de commodité", pero no parece que nuestro ms. fuera uno de ésos, ya que no se menciona en la lista de las adiciones ${ }^{3}$. Existe una sola pista. En un antiguo catálogo de la colección, redactado por Isaac Vossius en 1655, se menciona un ms. de "poeti spagnouli" 4 . El catálogo de Vossius fue ampliado y verificado en 1656 por un bibliotecario desconocido, que puso asteriscos en las descripciones de los libros. Este asterisco falta en la descripción del ms. de "poeti spagnuoli" y en la de algunos otros libros, lo cual nos hace suponer que el códice que Vossius vio en 1655 no fue encontrado un año después ni tampoco a fines del siglo, cuando se redactó el catálogo que más tarde aparecería en la bibliografía de Montfaucon. Aunque no puedo dar razón de las vicisitudes del ms. desde 1655 hasta su reaparición en tiempos recientes, 'no dudo en considerarlo el mismo códice de "poeti spagnuoli", en vista de que en toda la colección (en su estado antiguo o en su estado moderno) no hay ningún otro ms. que pueda designarse así. No he averiguado la historia del cartapacio antes de su adquisición por la reina Cristina, porque falta toda indicación de propietarios anteriores.

A don Ramón Menéndez Pidal se debe la única noticia que he visto sobre este ms. En su Romancero tradicional, t. 1, p. 119, transcribe un romance del rey Rodrigo (cf. infra, núm. 56) con la siguiente nota: "De este romance no nos era conocida ninguna versión sin glosar hasta que en febrero de 1911 apareció una en la Biblioteca Vaticana. Hállase en un cartapacio anterior a 1586: Biblioteca Vaticana, ms. Regina lat., 1635, fol. 126a"5. Dudo que Menéndez Pidal conociera directamente el ms., porque su importancia le habría inspirado algún comentario sobre su contenido. Alguien debió de haberle facilitado la información. Es fácil que la treintena de romances que hay en nuestro cartapacio estén incluidos en el gran archivo de don Ramón, pero hasta ahora no se han impreso, ni han sido descritos ni comentados, con la excepción que queda señalada.

El volumen, en $4^{\circ}$, mide $245 \times 185 \mathrm{~mm}$.; consta de 137 folios numerados, más una hoja que sirve de cubierta y un folio sin numerar entre el 111 y el 112. Hasta el $15 \mathrm{r}$, las planas están escritas a una columna, y a dos columnas a partir del $15 \mathrm{v}$, excepto cuando se trata de poemas en que hay endecasílabos. La mayor parte del ms. es obra de un solo copista, que terminó su tarea en el f. 131r. Una segunda mano añadió varias poesías más, hasta el $135 \mathrm{v}$. El volumen termina con dos copias de un mismo soneto, realizadas por dos nuevas manos (ff. 136v y 137r). En un pedazo de papel pegado a la cubierta se leen estas palabras, parcialmente tachadas: "Este libro es del señor Martín de... enueresa 4 de agosto de $1586^{\prime \prime}$.

3 J. Bignami Odier, "Le fonds de la Reine à la Bibliothèque Vaticane", Collectanea Vaticana in honorem Anselmi M. Card. Albareda, Città del Vaticano, 1962, t. 1, pp. 177 y $178-180$.

4 Cod. Vaticanus Latinus 8171, p. 156.

5 Al parecer, Menéndez Pidal no conocía la versión sin glosar de este romance que figura en el Canc. Classense, núm. 73, f. 74r.

6 Hasta ahora he trabajado a base de fotocopias, pero veré el original antes de 
Es difícil determinar la fecha y el lugar de la compilación. La fecha de 1586 es un terminus ante quem, pero como la mano que la escribió difiere de las otras cuatro que figuran en el cuerpo del ms., es lógico concluir que los textos se copiaron en época anterior. El cancionero reproduce un texto de la Diana de Montemayor, publicada en 1559, de modo que esta fecha puede considerarse como terminus a quo. Las afinidades que nuestra recopilación muestra con otros libros poéticos de la época -el Cancionero sevillano (ca. 1568), las Rosas de Timoneda (1573), la Flor de romances y glosas, canciones y villancicos (1578), las Poesias de Gregorio Silvestre (1582), el Romancero historiado de Lucas Rodríguez (1582) y el Thesoro (1580) y el Romancero (1583) de Pedro de Padilla- nos inclinan a situarlo en la década de 1570 a 1580. (En cuanto a las fechas tardías de los dos romanceros, es de notar que los romances correspondientes del cartapacio representan una etapa anterior a la de los impresos, bastante reelaborados) .

En cuanto al lugar, hay varios datos que apuntan a Sevilla. En primer lugar, el copista confunde las grafías $c-z-s$, y, como dice Amado Alonso, "la ciudad de Sevilla fue... un foco temprano del trueque [c-s], si no es que fue el primero". Basándose en observaciones de Arias Montano y otros contemporáneos, Alonso concluye que el fenómeno se constituyó en "un hecho de "lengua" en el período 1546-1566" Así, los muchos casos de confusión que aparecen en nuestro ms., copiado unos pocos años después, no tienen nada de sorprendente ${ }^{8}$. En segundo lugar, el Cancionero sevillano de la $\mathrm{H}$. S. A. tiene más textos coincidentes con el nuestro que cualquier otro libro, impreso o manuscrito. (Es verdad que esto puede deberse en parte al crecido número de textos que hay en el Cancionero sevillano: más de 650). Y lo que dice Margit Frenk Alatorre sobre ese ms. sevillano se aplica bien al nuestro: "[Es] un índice de los gustos de esos seudoliteratos sevillanos durante el tercer cuarto del siglo xvi, de su tradicionalismo en cuanto a formas y concepciones poéticas, de su débil e inexperto flirteo con la poesía al modo italiano; además, de sus poetas preferidos"9 (como Jorge de Montemayor, Diego Hurtado de Mendoza, Gregorio Silvestre y Pedro de Padilla). Finalmente, en el cartapacio se copia la controversia teológica entre Montemayor y Juan de Alcalá, "ropero de Sevilla", que según López de Toro es un disfraz que oculta a algún teólogo sevillano (cf. infra, núm. 124). El asunto era viejo (Montemayor murió

publicar la edición completa. Quizá la vista del original me permita descifrar las letras ilegibles. También es posible que el papel cubra otra anotación anterior, no visible en el microfilm.

7 Amado Alonso, "Historia del ceceo y del seseo españoles", BICC, 7 (1951), pp. 178 y 199.

$8 \mathrm{He}$ aqui unos ejemplos, tomados al azar: pasiençia (f. 16v), nasió (18v), riza 'risa' y aviza en rima con atiza (2lv), meresi (23r), graçioza (23v) (pero dañosa, $24 \mathrm{r})$, revez $(25 \mathrm{r})$, padeser $(25 \mathrm{v})$, Narcizo $(26 \mathrm{r})$, vensido $(27 \mathrm{r})$. E1 ejemplo rizaatiza-aviza, cuya rima sería imperfecta sin la confusión andalucista, indica origen sevillano no sólo del compilador, sino también del poema en que se encuentra. No es caso aislado.

9 Margit Frenk Alatorre, "El Cancionero sevillano de la Hispanic Society (ca. 1568)", NRFH, 16 (1962), p. 357. 
en 1561), pero evidentemente mantenía aún un interés local. En resumen, hay bastantes razones para suponer que nuestro ms. es sevillano.

Villancicos, canciones y glosas constituyen la mayor parte del cancionero. También hay otras formas tradicionales, como romances, coplas reales y de pie quebrado, y ensaladas. Hay asimismo un número respetable de poesías italianizantes: sonetos, tercetos, octavas, liras y sextetoslira. Los textos van agrupados en cuanto a su forma, castellana o italiana: una sección de sonetos, octavas, etc. va seguida de otra de villancicos, glosas y romances. Este esquema se repite varias veces, lo cual sugiere que el cartapacio es fruto de una elaboración lenta o bien planeada. Aunque los temas van de lo religioso a lo licencioso, predominan las poesías amorosas.

El hecho de que muchas de las composiciones se encuentren en otras fuentes (impresas o manuscritas) muestra que el compilador buscó sus materiales, como dice Margit Frenk Alatorre (loc. cit., p. 357), en "ese enorme caudal de poesías fugaces que, como bien mostrenco, emigraban de un cartapacio a otro, sufriendo continuos cambios, y que aparecían eventualmente impresos en alguno de los cancionerillos tan en boga por esos años". No hay indicación de que el compilador incluyera frutos de su propia musa. La nitidez de la escritura, las ocasionales lagunas sin llenar y la falta de enmiendas denotan el trabajo de un recopilador y no el de un espíritu creador. La mayor parte de los errores métricos y de las omisiones deberán atribuirse a las fuentes utilizadas, no al copista. El esmero es aún más afortunado para las composiciones que se conocen sólo gracias a este nuevo cartapacio.

Los poemas contenidos en el ms. suelen presentar bastantes variantes respecto de las otras versiones conocidas, por lo cual es necesario dar informaciones detalladas en cuanto a su forma. Sigo más o menos el mismo procedimiento que utilizó Margit Frenk Alatorre en su indice del Cancionero sevillano. Para los villancicos y canciones doy todo el estribillo y el primer verso de cada una de las coplas. Reproduzco la letra y los dos primeros versos de las glosas. En el caso de la poesía italianizante, los romances y las composiciones en coplas reales y en quintillas, transcribo los dos primeros versos y el último, con indicación del número de estrofas.

Transcribo en letra cursiva los títulos que indican la forma poética o el tema de las composiciones (salvo el título otras, que nada significa). Cuando falta información sobre la forma, la añado yo en letra redonda. Si no se consigna forma alguna, es que se trata de un villancico o una canción, llamados generalmente letra o coplas en el cartapacio.

Reproduzco la ortografia del original, resolviendo las abreviaturas y modernizando la puntuación, la acentuación y el uso de mayúsculas. El orden alfabético sigue la ortografía antigua, pero incluyo referencias con ortografía moderna.

Señalo para muchos poemas las otras versiones impresas y manuscritas que he encontrado. Marco con asterisco las letras que se conocen en dos versiones o más, con desarrollos diferentes de los del cancionero, para indicar su popularidad y para abreviar el aparato bibliográfico. 
No pretendo haber reunido todavía una lista exhaustiva de referencias, pero las señaladas darán una idea bastante justa de la difusión de los textos.

Empleo las siguientes abreviaturas:

BöHL de Faber: JUAN Nicolás BöHL de FAber, Floresta de rimas antiguas castellanas, Hamburgo, 1821-1825.

Canc. Classense: Antonio Restori, "Il Cancionero Classense 263", Rendiconti della R. Accademia dei Lincei, 5a serie, 2 (1902), 96-136.

Canc. Juromenha: Carolina Michä̈LIs DE VAsconcelos, "Mitteilungen aus portugiesischen Handschriften, I. Der Cancionero Juromenha", ZRPh, 8 (1884), 430-448.

Canc. Oxford: KarL Vollmöller, "Mittheilungen aus spanischen Handschriften, I. Oxford All Souls Coll. No 189", ZRPh, 3 (1879), 80-90.

Canc. Riccardiano $I$ y $I I$ : Eugento Mele y Adolfo Bonilla y San Martín, "Dos cancioneros españoles", RABM, 3a época, 10 (1904), 162-176, 408-417.

Canc. sev.: MARgit Frenk Alatorre, "El Cancionero sevillano de la Hispanic Society (ca. 1568)", NRFH, 16 (1962), 355-394.

Cartapacios: Ramón Menéndez PIDAL, "Cartapacios literarios salmantinos del siglo xvI", BRAE, l (1914), 43-55, 151-170, 298-320.

“136 sonnets": R. FoulchÉ-Delbosc (ed.), "136 sonnets anonymes”, RHi, 6 (1889), 328-407.

Chevalier: Maxime Chevalier, Los temas ariostescos en el romancero y la poesia española del Siglo de Oro, Madrid, 1968.

Esteve Barba: Francisco Esteve Barba, Catálogo de la colección de manuscritos Borbón-Lorenzana, Madrid, 1942, núm. 506 (400-424): [Poestas de varios autores...].

Figueroa: Francisco de Frgueroa, Poesías, ed. A. González Palencia, Madrid, 1943.

Flor: Flor de romances y glosas, canciones y villancicos... (Zaragoza, 1578), ed. A. Rodríguez-Moñino, Valencia, 1954.

Flores: Flores de baria poesía, recogida de varios poetas españoles... México, 1577, ms. 2.973 de la B.N.M., descrito por José Simón Díaz, Biblia grafía de las literaturas hispánicas, t. 4, Madrid, 1955, pp. 81-82.

Gallardo: Bartolomé José Gallardo, Ensayo de una biblioteca española de libros raros y curiosos, Madrid, 1863-1889.

Hispanic Soc.: Antonio Rodríguez-Moñino y María Brey Mariño, Catálogo de los manuscritos poéticos castellanos existentes en la biblioteca de The Hispanic Society of America, New York, 1965.

Laynez: Pedro Laynez, Obras, ed. J. de Entrambasaguas, t. 1, Madrid, 1951.

López de UBEDA: Vergel de flores ditinas... por Iuan López de Vbeda, Alcalá de Henares, 1582.

Montemayor: El Cancionero del poeta George de Montemayor, ed. A. González Palencia, Madrid, 1932.

Padilla, Romancero: Pedro de Padilla, Romancero, Madrid, 1583.

Padilla, Thesoro: PfDro de Padilla, Thesoro de varias poesias, Madrid, 1580.

París 314, 307, 372, 373, 371: ms. "Esp. 314", etc., de la B.N.P. (A. MoreLFAtio, Catalogue des manuscrits espagnols de la Bibliothèque Nationale, t. 1, Paris, 1881, núms. 598 y 600-603, pp. 206-207). El núm. 314 ha sido editado (véase LAYNEZ).

Pliegos: AnTonio Rodrígurz-Moñino, Diccionario bibliográfico de pliegos sueltos poéticos (siglo xyi), Madrid, 1970. 
Rom historiado: LUCAS RodRícuez, Romancero historiado (Alcalá, 1582), ed. A. Rodríguez-Moñino, Madrid, 1967.

SrLvestre: Las obras del famoso poeta Gregorio Silvestre, Lisboa, 1592.

Timoneda, Rosa de amores, Rosa gentil: Rosas de romances por Juan Timoneda (Valencia, 1573), ed. A. Rodríguez-Moñino y D. Devoto, Valencia, 1963.

"Tres cancs.": ANTonio RodRíguez-MoÑino, "Tres cancioneros manuscritos. (Poesía religiosa de los Siglos de Oro)", Ábaco, 2 (1969), 127-272; 3 $(1970), 87-227$.

Zarco: Julián Zarco, "Un cancionero bilingüe manuscrito de la biblioteca de El Escorial", Religión y Cultura, 24 (1933), 406-449.

University of Missouri.

Harold G. Jones, III

\section{INDICE DEL CANCIONERO}

1. A don Roldán le contaua / sus desventuras vn día... la que ninguna tenía (rromançe de cómo contó Ysabella su desventura a Orlando): $62 \mathrm{v}-63 \mathrm{v}$. (Cf. núms. 45 y 54 ).

*2. Afuera, consejos vanos / que despertáis mi dolor; / no me toquen vuestras manos, / que en los consejos de amor / los que matan son los sanos. // Consejos de mi memoria / que lucháis con mi dolor... (glosa): 18v s. (En Flor, pp. 256-258, con texto defectuoso).

*3. [Afuera, consejos vanos...]. Dama, si queréis q[ue] os ame / de muy firme coraçón... (glosa); 45r-v.

* 4. [Afuera, consejos vanos...]. ¿Para qué me perseguís, / cuydados? ¿Por qué no os uais?... (glosa): $73 \mathrm{v}$.

*5. [Afuera, consexos vanos...]. Ha querido mi ventura / que yo sea enamorado... (glosa): 18r-v. (La letra y glosa en Padilla, Thesoro, ff. $363 \mathrm{v}-364 \mathrm{v})$.

6. Al Amor burla[n]do / le hirió Luisa, / y él quedó llorando / y ella con gran rriza. // 1) Del arco y aljaua, 2) $Y$ al tienpo que Amor, 3) No le osa pedir, 4) Él muy bien quisiera: $21 \mathrm{v} s$.

7. A la sonbra de vna haya / Durandarte está apeado... que ansý lo tiene jurado (rromance): $66 \mathrm{r}-67 \mathrm{r}$.

* Alçé los ojos por veros, / baxélos después que os vy, / porque no ay pasar de ally / ni otro bien sino quereros. // Tanto bien en ueros siento, / tan dulcemente matáis... (glosa): 96r-v. (La letra es de Jorge de Montemayor, Diana, ed. F. López Estrada, Madrid, 1946, pp. 148-149; la glosa es de Silvestre, ff. 78v-80r) .

9. Alegre estoy, carillo, grandemente / del fabor de vna ninpha no pensado... tú gozarás el fruto que se espera (soneto a vna dama que le pidió vn galán vn clauel y le dio vna pera): 78r. (Atribuido a Cristóbal Pinelo en Esteve Barba, f. 319r).

10. Al más fino cristal, señora mía / exçede vuestro blanco y dulçe cuello... quanto soys dibuxada a lo diuino (soneto): $89 \mathrm{v}$.

11. Al que adama a vna / ayúdele su ventura; / y el que adama a dos, / no le ayude Dios. // 1) El que con amor se atreue, 2) El que es amador tronpero, 3) Amor, a quien tú le das, 4) Al que muda cada día, 5) Al falso $v$ loco amador: 101v. [Faltan los tres últimos versos 
de la cuarta estrofa]. (En Canc. Classense, f. 65r ["El que ama a una'], 4 estrofas).

12. Alrrededor de Çamora / andaua el Çid castellano... libre con vitoria y salvo (rromance): $50 \mathrm{v}$ s. ("Tres cancs.", citado en Ábaco, 2, p. 195; reproducido en Ábaco, 3, pp. 155-156).

13. Amar y a nadie dezirlo / es dentro del pensamiento / vn género de tormento, / que dudo para sufrirlo / ser bastante el sufrimiento. // El más difíçil precepto / que en la ley de Venus toca... (glosa): $43 \mathrm{v} s$.

*14. Amor me tiene puesto en tal estado, / qu'es semejante ya el tormento mýo... y en éste nunca ay puerto ny rreposo (soneto): $78 \mathrm{v}$. (En Canc. Oxford, f. 58r).

15. Amor no desordena el buen camino / que por naturaleza está ordenado... y menos dura amor en honbre loco. // Sy algún coraçón libre amor ynflama / tan perfeto lo dexa el fuego ardiente... (glosa): 92r-93v. (La letra parece ser una octava de Montemayor, aunque no figura en su Cancionero, ed. 1932. Se halla atribuida a él en el ms. 1649 de la Univ. de Barcelona, f. 27v, y en Canc. Riccardiano $I I, \mathrm{f} .15 \mathrm{v})$.

Amor y su contrario..., véase Quien dize que el ausençia causa oluido.

16. Andáos a enamorar, por uida mía. // 1) Vn tiempo fue el amor tan verdadero, 2) Amor con otro amor era pagado, 3) Ya las damas desechan las cançiones, 4) Las músicas de noche les dan pena... (glosa) (liras de siete versos, AbCabCC) : 75r-76r.

17. Andaua el buen San Francisco / por los montes apartado... fue de tal gloria dotado (rromançe de Sanct Francizco): 59v s. (Pliegos, núm. 657; Silua de romances [Zaragoza, 1550-1551], ed. A. Rodríguez-Moñino, Zaragoza, 1970, pp. 106-107).

18. A pie estaua Durandarte, / a pie está, que no a cavallo... el alma se le ha arrancado (rromançe): 126r-v.

19. Aquella linda zagala, / que amor no pudo vencella, / irrayo malo caya en ella! // 1) Rayo no para matarla, 2) Rayo de amor ençendido, 3) De todos sus seruidores: $47 \mathrm{v}$.

20. Aquesta sin ventura y desdichada / epístola te enbio la postrera... de cuya pesadunbre se descarga (epistola) (20 tercetos): 36r-37r. (Respuesta al núm. 23).

*21. [A su albedrío y sin orden alguna...] // Los claros rrayos de la blanca luna / quando la deseada primavera... (glosa) (16 cuartetos): 121r-122v. (El poema glosado consta de 7 octavas en Canc. sev., ff. 265-266r. La glosa se limita a las dos primeras octavas).

22 A Tántalo nos pinta la poesía / metido hasta el pecho en vna fuente... y quando más alcança es vna mano (soneto): $34 \mathrm{v} s$.

23. A ty, Celia cruel, desconosida, / muy más que tigre yrcana brava y fiera... y qué mal la amistad que conservaste (epistola) (16 tercetos): 35r-36r. (Véase núm. 20).

24. Aunque estéis, mi bien, ausente. // 1) Quando os vide no biuía, 2) Quando con vos y sin my, 3) Puesto que yo no viuiera, 4) La lindeza milagrosa (glosa): $111 \mathrm{v} s$.

25. Aunque yo quiero ser beata, / el amor me lo desbarata. // 1) Mongil tomaría y toca, 2) Mirando my hermosura, 3) Ver otras damas luzidas, 4) Hago vn rrato burla dellas, 5) Prueuo vn día a rrecogerme, 6) Aunque sé qu'están muriendo, 7) Si pretendo rrepararme, 8) Adondequiera que esté: $97 \mathrm{v}$ s. (Canc. sev., f. $229 \mathrm{v}$, pero sólo el estribillo). 
26. Aviendo de partirse / vn pastor deste monte y su rribera... y el no tener presente a quien quisiera (despedida de vn pastor) (16 liras): 86r-88r. (Sólo 7 estrofas en Flor, pp. 261 ss. Es de Francisco de Figueroa: véase $R H i, 25,1911$, pp. 338-341).

27. ¡Ay Dios! jay mi pastora! / iy quánto me lastima estar sin uerte!... pensar que cure el tienpo mal tamaño (10 liras de don Diego de Mendoça a vna ausençia de vna dama): 74r-v. (Se halla también en el Cancionero de 1628, ed. J. M. Blecua, Madrid, 1945, pp. 325-326, y en Paris 372, f. 194v).

*28. - ¡Ay, que el alma se me parte! / -Coraçón, ¿por quién sospiras? / -Porque te miro y me miras / sin gozarme ni gozarte. // Gran Dios a quien ofendí, / dame fuerça, dame aliento... (glosa): 16r-v. (SILVESTRE, 326r-327r).

29. Belisa a su Menendro [sic] por quien viene / el alma que lo amó justo castigo... y así quedó esperando la rrespuesta (epistola) (4.3 tercetos) : 29r-31v. (Paris 372, ff. 94 ss.; Flores, ff. 95-97v; atribuido a don Diego de Zúñiga en Canc. Riccardiano II, f. $36 \mathrm{v}$, y a Juan Iranzo en Esteve Barba, ff. 41r-45r. Cf. núm. 221).

30. Belisa, no contento con mirarte, / quise yo dibuxar tu gentileza... sino que la primera sea postrera (4 otauas): $38 \mathrm{r}-39 \mathrm{r}$.

31 Benita, no ay para qué / tú me digas que me quieres, / pues sé que penas y mueres / por otro con mayor fee. // 1) Benita, por muy mejor, 2) Aunque amor no admite engaño, 3) No cabe en ley de rrazón, 4) Falta es de conocimiento: 127r. (En Canc. serv. f. 245v s.).

*32. Biue leda si podrás / y no penes atendiendo: / que según peno partiendo, ya no esperes que jamás / te veré ni me verás. // Señora, sin ti y comigo, / ¿dónde yré, que voy $\sin$ my?... (glosa): $125 \mathrm{v} s$.

* 33 Biue leda si podrás... // Vaya la pena en que estamos / comigo, pues que me voy... (glosa): 15v s. (La letra y la glosa en el Suplemento al "Cancionero general", ed. A. Rodríguez-Moñino, Madrid, 1959, núms. 301-302; la glosa empieza "Vaya la pena de entramos". La letra es de Juan Rodríguez del Padrón).

34. Blasfemando de sus dioses / el rrey de Carça salía... nesesidad lo tenía (rromançe): 61v-62v. (En Rom. historiado, p. 144, donde empieza "De sus dioses blasfemando". Véase Chevalier, pp. 79-81, y cf. núms. 78 y 109).

35. Burléme con Amor, Amor comigo / burláuame. Con él quedé burlado... escarmentad, pues, ya en cabeça ajena (soneto): 1r. (Es de Alonso Pérez: véase $B A E$, t. 42, p. 504).

36. Carillo, ya no ay contento, / ya el plazer se me acabó, / y en su lugar me dexó / suspiros, ansia y tormento. // 1) Ya se acabaron los días, 2) En tan abscondida parte: 25r. (Paris 314, f. 195 s.; publicado en LAYNEz, pp. 411-412. También Canc. sev., f. 238v).

37. Católica magestad, / por serbille estoy perdido... señor miserere mey (Vna carta que un soldado dio al rrey don Felipe de rrequesta) (14 quintillas seguidas por un romance): 131v-132v. [Segunda mano]. (También en Paris 373, ff. 225r-228r).

38. Cerca de Hierusalén / vna muger abitaua... para donde fue criada (rromançe): $99 \mathrm{r}-\mathrm{v}$.

39. Con Angélica la bella / fue gran tienpo enamorado... la trayga algún buen estado (rromançe): 112r-v.

40. Con el gran señor de Anglante / Isabella caminaua... y palabras estorvaua (rromançe): empieza en el recto del folio sin número entre 111 y 112; termina en $112 \mathrm{r}$. 
41. Con esos cabellos / me lleuáis asido. / Suéltame, zagala, / que ya estoy rrendido. // 1) Esos tus cabellos, 2) Suéltame el tormento, 3) El alma te he dado, 4) No sé qué más quieres: 22r.

42. Con los ojos de Ysabel / el amor tira a quien quiere, / y con los de Ana hiere / quando se muestra cruel. // 1) Los ojos que Ysabel tiene, 2) Dichoso aquel que pretende: 25 r.

43. Con my ganado acaso llegué vn día / en vn vmbroso valle muy cerrado... quál más herido o más penado fuese $(5$ octavas reales de Silvestre): 85r-86r. (Pliegos, núm. 722: Paris 314, ff. 213v-215r; en LaYNFZ, pp. 439-434, son 6 las octavas).

44. ¿Con qué piensas, María, enterneçerte, / pues no vale contigo vn amor puro?... y a ti de ser vn grande majadero (13 terçetos a vna dama cudiçiosa): $80 \mathrm{v}-81$.

Consejos de mi memoria..., véase Afuera, consejos vanos.

45. Con su querido Vireno / contenta Olinpia biuí... y en libertad la ponía (romance): 64v-65v. (LoRenzo dE SEpúlveda, Cancionero de romances [Sevilla, 1584], ed. A. Rodríguez-Moñino, Madrid, 1967, p. 333. Véase Chevalier, pp. 133-135, y cf. núms. 1 y 54).

*46. Contentamiento, ¿dó estás?, / que no te tiene ninguno. / Quien piensa tener alguno / no sabe por dónde vas. // Contento, si tú te dieses / como yo te pediría... (glosa): $45 \mathrm{v}$ s. (Cartapacios, p. 46, atrib. al Duque de Sesa; Rom. historiado, pp. 201-202. Incluida por JUAN Díaz Rengifo en Arte poética española [1592], p. 73 de la ed. de 1759) .

47. - ¿Cre[é]ys que soys más hermosa / que quántas he uisto y veo? / Dezý, señora. -Sí creo. // 1) ¿Creéys que del alma mya...?, 2) ¿Creéys que se trasladó...?, 3) ¿Creéys que vuestra memoria...?, 4) ¿Creéys que vuestra lindeza...?, 5) ¿Creéys que fue venturoso...?, 6) ¿Creéys que biuo y rrespiro...?: 72r.

Cualquiera, véase Qualquiera.

Cuando, véase Quando.

Cuitado, véase Qüitado.

48. Cuydados, mal me tratáys, / fatigas, no me canséis; / mirá que si me acabáys / que comigo acabaréis. // 1) No tanta priesa al morir, 2) Afloxá el trato crüel: 97r. (Diego Hurtado de Mendoza, Obras poéticas, ed. W. I. Knapp, Madrid, 1877, pp. 364-365, donde comienza "Cuidados, gran priesa os dais..."; también en Canc. sev., f. $67 \mathrm{v}$ s., con primer verso como el nuestro).

49. Da Dios mal para más bien, / mas a mí, por ser vos tal, / me dio bien para más mal. // Da Dios mal al pecador / en pago de su pecado... (glosa): $17 \mathrm{r}$.

50. De amores está Fileno / aburrido y maltratado... no sea de ty olvidado (rromançe): 54v-56r. (TImoneda, Rosa de amores, ff. 18v-20r; Rom. historiado, pp. 197-198; también en Canc. Oxford, Canc. sev., Paris 314; LAYNeZ, pp. 378-379).

51. De amor soy burlado / con burla amorosa, / y soy namorado / de vna fea graçioza. // 1) Estando en mi aldea, 2) Fayción por fayción, 3) Su talle y su gesto, 4) Es cariaguyleña, 5) La boca tendida, 6) Y con uer que veo, 7) Quando la miré, 8) Y lo que aprouecha: 23v-24v.

52. De amor y de su pena descuydado, / libre de su dolençia y de su fuego... con uer que amor me mata por tu mano (3 octauas): $119 \mathrm{r}-\mathrm{v}$. (La primera de las tres octavas está incorporada a un romance de 
Rom. historiado, "Orilla del sacro Henares", pp. 190-191).

De hoy más si por traidor..., véase Pues tuue coraçón...

*53. De la dulçe mi enemiga // nasçe vn mal que l’alma hiere, / por más tormento quiere / que se sienta y no se diga. // Quando sube el pensamiento / donde yo tengo el querer... (glosa): $108 \mathrm{v} s$.

54. De la furia de los vientos / en alta mar contrastado... y los dexó en su condado (rromançe de Olinpia quando contó sus desventuras a Orlando): 63r-64v. (Cf. núms. 1 y 45).

55. De la sangrienta batalla / en que Carlos fue vençido... a entranbos han suçedido (rromançe): $112 \mathrm{v} s$. amortesido (rromançe): 126 r. (Reproducido en R. Menéndez Pidal,

56. De las batallas cansado / se sale el rrey don Rodrigo... cayó el trizte Romancero tradicional, t. 1, Madrid, 1957, p. 119; también en Canc. Classense, núm. 73 , f. $74 \mathrm{r}$, y, sólo en forma glosada, en varias colecciones del siglo xvi. Véase supra, nota 5).

57. De los dolores que siento, / ¿qué tal será el galardón / si se yguala mi pasión / con vuestro meresimiento? // 1) Avnque ay mucha diferencia (letra y 1 copla real): 47r. (Hispanic Soc., núm. XXIV, p. 20: Paris 307, f. 24lv; Paris 371, f. 23r-v; la letra en Silvestre, ff. $83 v-84 v)$.

58. Del valiente sarracino / Ferragut fiero y gallardo... que será mejor dexallo (rromance): 114r-v.

59. Dentro de Valladolyd, / esa villa tan nonbrada... cunplyó muy bien su palabra (rromançe): 105r-v.

De oy más si por traidor..., véase Pues tuue coraçón...

*60. De piedra pueden dezir / que son nuestros coraçones: / el mío en sufrir pasiones, / y el vuestro en no las sentir. // Los que saben que os amé, / señora, desde la cuna... (glosa): 127r-v.

*61. Desde el coraçón al alma / determino de mudaros, / para jamás olvidaros. // Por el ṕreçio de valor / y del alma en sus dolores... (glosa): 28r. (La letra y la glosa en París 372, f. $104 \mathrm{v}$, atrib. a D. L. [don Diego de Leyva?]) .

*62. Desde el coraçón al alma... // 1) En este aposento tal, 2) Este aposento cerrado, 3) Aurá en estos aposentos, 4) Porque gozase de veros, 5) Perpetuo será el querer: $44 \mathrm{v} s$. (Silvestre, f. $112 \mathrm{r}-\mathrm{v}$, con sólo 4 estrofas).

63. Después que aquella batalla / tan espantosa y rreñida... de la rribera partía (rromançe): 113-v.

*64. Después que mal me quisistes, / nunca más me quise bien, / por no querer bien a quien / vos, señora, aborresistes. // En estos estremos dos, / en el fabor y el desdén... (glosa): 14v-15v. (Silvestre, ff. 81r$82 v$ ).

65. -Di, carillo, ¿por qué estás / los ojos de agua tan llenos? / -Porque voy queriendo más / y Menga queriendo menos. // 1) Siendo tan rregozijado, 2) Líbrate de su tormento: 103r-v.

66. -Di, Gil, ¿qué siente Juana que anda triste, / pues no le falta graçia y hermosura? / -Fáltale lo mejor, que es la ventura. // 1) Estoy ymaginando la tristeza, 2) Quando nuestra pintura disponía, 3) En ella extremos grandes concurrieron, 4) Naturaleza estaua muy gozosa, 5) La clara luz del día conparada: 120r-121r. (Sólo la letra en Canc. Oxford, f. 106r; Paris 371, f. 214; Padilla, Thesoro, f. 237v) .

67. Diome en pago del amor / una dama a quien seruía... mill penas a vna alegría, / iqué tiranía! (rromançe): $21 \mathrm{v}$. 
68 Disculpa yo no la sé / ni es posible que se vea / del galán qu'en muger fea /pone su firmeza y fee. // 1) El amor de vn rrostro feo, 2) La disculpa más osada, 3) La fea con el parlar, 4) Ello es querer al rreuez: $24 \mathrm{v} s$.

*69. -Di, zagala, ¿qué harás / quando beas que soy partido? / -Carillo, quererte más / qu'en mi bida t'é querido. // 1) Después que d'aquí partiere, 2) ¿Por qué sospechas mudança...?, 3) Antes desta mi partida, 4) ¿Cómo puedes tú morir...?: 135r-v. [Segunda mano]. (Montemayor, pp. 18-19; Canc. sey., f. 298r; Cancioneiro de Évora, ed. A. L.-F. Askins, Berkeley, 1965, p. 34 [sólo una estrofa]. En los dos primeros la letra empieza: "Zagala, di qué harás...").

70. Duélete de mi pasión, / zagaleja, / que quien te hizo león / te podrá hazer oveja. // 1) Si tu lindeza te yncita, 2) Yo entiendo que mi tristura, 3) En saber aborrecer, 4) no deues tratarme mal: $103 \mathrm{v} s$.

71. Duerme, carillo, a buen sueño, / descansa y mira por ty, / y ten por cierto de my / de no tener otro dueño. // Zagal, como quantos son / a quien yo soy tan fiel... (glosa): 48v s. (Canc. sez., f. 298v s.: sólo es igual la letra, y ésta con variantes: "Carillo, duerme a buen sueño...") .

72. EI consejo, justiçia y rregimiento, / y muchos honbres buenos del aldea... se fueron cada vno a su posada (soneto): $88 \mathrm{r}$. (El primer verso es igual a un soneto de tema parecido de Padilta, Thesoro, f. $430 \mathrm{r}$ ).

73. El mal que amor me á dado, / sy alguna parte dél mostrar pudiera... que aunque me maltratéis, no he de oluidaros (epistola) (14 liras): $93 \mathrm{v}-95 \mathrm{r}$.

74. El mayor mal es morir, / y si ay alguno mayor / es amar do no ay amor. // 1) La muerte de vna herida, 2) El mal que muerte lo cura, 3) Muriendo çesa el biuir: 11lr-v. [Faltan los tres últimos versos de la primera estrofa]. (Canc. Juromenha, f. 89).

75. El soberuio Rodomonte, / de Doraliçes negando... las armas o el cavallo (rromançe): 123r-125v. (PADILla, Romancero, ff. 157v-160r. Véase Chevalirer, pp. 99-101).

76. El valiente don Manuel, / ese león afamado... quando sea enamorado (rromançe): 129r-v.

77. En el çielo dos estrellas / se hizieron tranpantoxos, / y de entranbas a dos ellas / se formaron vuestros ojos. // 1) Muy gran ocasión tuuieron, 2) Son agora luz del alma, 3) Juntas todas las más bellas: $111 \mathrm{v}$.

78. En el solene conbite, / siendo Rugero casado... quedó rrespuesta esperando (rromançe de Rodamonte): $60 \mathrm{v} s$. (PADILlA, Romancero, ff. 179v-181v. Véase Chevalier, pp. 217-219, y cf. núms. 34 y 109) .

79. En el tienpo de los godos, / que no auía rrey en Castilla... que en España rresidían (rromançe): 100v s. (TrmonedA, Rosa gentil, ff. $57 \mathrm{r}$ 58v; Silva de varios romances recopilados por Juan de Mendaño [Granada, 1588], ed. A. Rodríguez-Moñino, Valencia, 1966, ff. 30v31v; Paris 373, f. 53; "Tres cancs.", Ábaco, 3, pp. 124-125. Nuestro texto concuerda bien con Paris 373 y "Tres cancs.", y menos bien con los primeros dos, que tienen seis versos más al fin, entre otras variantes) .

* 80. En la peña, junto a la peña, / duerme la niña y sueña. // 1) La niña, de amor herida, 2) Con su amador se soñaua, 3) Hallóse tan afligida, 4) De rremedio desespera: $126 \mathrm{v}$ s. (Diferente del poema cono- 
cido: véase José MARÍA ALíN, El cancionero español de tipo tradicional, Madrid, 1968, p. 520).

En lo más dificultoso..., véase Quien pierde por vos la uida.

81. En los algibes del agua / que allá en [e]l Alhanbra auia... Él la dio por bien perdida (rromançe): 100r-v.

82. En mi fe mayor firmeza. // 1) Aunque dexase de ser, 2) El coraçón de mi pecho... (glosa): $73 \mathrm{r}$.

83. En una pequeña villa / que El Alameda se llama... y cómo lo madrugaua (rromançe): 102r-103r.

84. En un campo me metí / a lidiar con mi deseo: / contra mí propio peleo, / defiéndame Dios de my. // Amor y desconfiança, / siendo mis conpetidores... (glosa): 9v-10v. (La letra en Zarco, p. 444, y "Tres cancs.", citado en Ábaco, 2, p. 218).

85. Esçelço monte do el rromano estrago / eterna dexará vuestra memoria... el tienpo derribar podrá mis males (soneto hecho por Aldana quando salió de Tunis): 136v. [Tercera mano] (Véase R. FoutCHÉ-Delbosc, "Notes sur le sonnet Superbi colli", RHi, 11, 1904, pp. 228-231).

86 - [Transcripción del poema precedente por cuarta mano en el f. $137 \mathrm{r}$, sin variantes].

87. Esperança me despide, / tristeza no me faleçe... mucho más qu'esto mereçe (rromançe): 135v. [Segunda mano]. (Difiere bastante de las versiones conocidas: Cancionero de romances [Amberes, 1550], ed. A. Rodríguez-Moñino, Madrid, 1967, f. 250r-v; Cancionero de Juan Fernández de Constantina, ed. R. Foulché-Delbosc, Madrid, 1914, núm. 181; Timoneda, Rosa de amores, ff. 6lv-62r).

88 [Estáuase Marfida contenplando]. Forçada de amoroso sentimiento / y de otros mill extremos conbatida... (glosa del soneto de Marfida) (14 octavas) : 90r-92r. (Soneto en Montemayor, p. 44. Hay una glosa [ala misma?] pór Joaquín Romero de CEPEda, Obras, Sevilla, 1582: véase Gallardo, t. 4, núm. 3707).

89. Estoy de amor lastimado, / desabrido y descontento, / porque no siento que sientes / lo que siento. // 1) Estoy puesto en tal estremo, 2) Verdad es que si el amor, 3) Buelue esos hermosos ojos: 5lv.

Excelso, véase Esçelço.

Forçada de amoroso sentimiento..., véase Estáuase Marfida...

90. Fortuna con ymbidia, avnque secreta. / llorando vn día se llegó a Luysa ... que aquý paso la silla de my ynperio (soneto): $77 \mathrm{r}$.

91. Fortuna me a de acabar, / pues en mis bienes procura / que quando tenga ventura / me falte tienpo y lugar. // 1) ninguna cosa me queda, 2) $Y$ porque mi mala suerte, 3) Perder bien o desearlo, 4) La Fortuna, de ymbidiosa: 106r. (En Paris 372, f. 322v, y en SiLVESTRE, ff. 99v-100v) .

Forzada, véase Forçada.

92. Gileta, Juana ni Anilla, / ni Menga ni otra muger, / ninguna tiene que ver / con el pie de Hieromilla. // 1) Yo conozco que Gileta, 2) Antes de auerlo mirado, 3) Bien sé qu'es hermos[a] Elena, 4) Aquel mirar tan süave: $46 \mathrm{v}$.

93. -Gil, ¿qué haré, que estó enamorado / de Ju[a]na, y nada por mí se le da? / -Súfrelo y calla, que tienpo vendrá / que ella te rruegue y tú quedes vengado. // I) Quien biue muriendo mal puede sufrir, 2) Si el mal que padesco no fuese tan fuerte, 3) quiero seguirme por tu paresçer: $130 \mathrm{v} s$. 
94. Gloria no á de pretender / quien no gusta este manjar, / porque no gustó en comer / quanto Dios le pudo dar. // 1) El alma de gracia pobre, 2) Alma qu'en su fundamento, 3) Mas aduierta el conbidado: 25r-v.

95. Gran diablo, Leonor, se te á metido / en ese coraçon, que asý lo á hecho... serán las veynte cruzes veinte escudos (soneto): 89r-v. (Canc. sev., f. $5+v$, soneto con estrambote, que termina: "con que se alcansará el que arriedro vaya").

Habiendo, véase Aviendo.

Hacia, véase Hazia.

*96. Ha de ser vna de dos... // Para subir mi ventura / a vn extremo sin medida... (glosa): 72r-v.

*97. Ha de ser vna de dos: / soledad o sola vos. // Quando estoy en vuestra avsencia, / en contenplar me sustento... (glosa): 19r-v.

98. Hazia la ysla de Traçia / vna donzella biuía... a tenerle conpañía (rromançe): $122 \mathrm{v} s$.

*99. He dado en dárseme poco / por tus locuras, Amor, / y vame tanto mejor / quanto va de cuerdo a loco. // 1) Ya, Cupido, no me aplazen, 2) Pensar que serás fiel, 3) Hállome sin tu cuidado, 4) Ya no me harás más daño: $72 \mathrm{v} s$.

Hoy, véase $\mathrm{Oy}$.

100. Huie, zagal, el biuir, / que la vida, que la vida / es la cosa más perdida / que a ti te puede venir. // 1) Si mueres con acabar, 2) ¿De qué te sirue esperar...?, 3) Si morir es el rremedio: 25v.

101. Hurtóle vna toca a Elvira / Cupido, el amor crüel, / y ella por vengarse dél / ále tomado la vira. // 1) Para mejorar su venda, 2) Como lleuó Amor la toca, 3) Ved si se á puesto en aprieto, 4) Tantos mata Elvira y prende [se repite la estrofa 4 a] : $49 \mathrm{v} s$.

Huye, véase Huie.

102. Juan García, venís loco? / v ¿qué diablos traéis? // 1) Ella començó a gritar [intercalada en una ensalada, núm. 191]: 53r.

103. Jugauan almas certero / Ynterés y el Amor franco; / Ynterés daua en el blanco / y Amor erraua el terrero. // Sus varios arcos armados, / Ynterés y Amor vn día... (glosa): 19v s.

104. Jugauan almas certero... y Amor no en todo el terrero. // Estando Amor enojado, /desechó toda pasçiençia... (glosa): 47r-v.

*105. La bella mal maridada, / de las más lindas que vy, / si auéis de tomar amores, / vida, no dexéis a mí. // Hanse en mi fabor mostrado / tanto el amor y fortuna... (glosa): 5r-6r.

106. La casa que en Nazarén / la sacra virgen María... muy bastante y muy cunplida (rromançe de vin milagro de Nuestra Señora): $70 \mathrm{r}-\mathrm{v}$.

107. La fama que procura engrandeseros / os pinta sobre todas tan hermosa... y nadie la verá que no la alabe (soneto): 78r-v. (Figueroa, p. 135) .

108. Lágrimas que mis ojos vays bañando, / suspiros que mis pechos vais rronpiendo... que adonde rreyna amor todo es posible (soneto): 40r. (En Flores, f. 263v; también París 373, f. 128. Está incorporado a un romance pastoril de Rom. historiado que empieza "Orilla del sa. cro Henares", pp. 190-191).

109. La hermosa Bradamante, / del mal de amores herida... que tanto mal le hazía (rromançe): 61 r-v. (Cf. núms. 34 y 78). 
110. La mejor muger, muger, / y la más cuerda de lana, / la más onesta liviana, / y la de más ser sin ser. // Formó la mano eternal / la henbra para el varón... (glosa): 8r-9r. (El núm. 119 del Canc. Classense, f. 102r, tiene la misma letra, con un desarrollo diferente).

*111. Las tristes lágrimas mías / en piedras hazen señal, / y en vos nunca, por mi mal. // Mis ojos quando os miraron, / si contento recibieron... (glosa): 110r-v. (La letra y la glosa en Padilla, Thesoro, f. $289 \mathrm{r}-\mathrm{v})$.

112. La triste Muerte y el Amor salieron / tirando vn día con sus flechas duras... y ella me tira y dobla mi cuydado (soneto): $119 \mathrm{v} s$. (Se halla en el ms. 381 de la B.N.M., atribuido a "Couarruuias": reproducido en "237 sonnets", ed. R. Foulché-Delbosc, RHi, 18, 1908, núm. 172, p. 577).

113. Levantaos, marido mýo, / que es ora de levantar. // I) Despertad, que yo os enpeño, 2) En vn cabo de tizón, 3) No os durmáys, por vida mía, 4) El ynvierno ya pasado: 52r. [Intercalada en una ensalada, núm. 191].

114. Los cabellos, iqué cabellos!, / Siluia, no se vio pastor; / lazos son que tiene Amor, / con que prende sólo en vellos. // 1) Ya su arco poderoso: $44 \mathrm{r}$.

Los claros rrayos de la blanca luna..., véase A su albedrío y sin orden alguna.

*115. Los ojos con que os miré / quiziera luego sacar, / pues me hizieron desear / lo que nunca alcançaré. // Aquel que vna vez os uiere, / viendo en vos lo que yo vy... (glosa): $48 \mathrm{r}$-v.

116. Los ojos que vna vez pudieron veros, / ¿qué más tienen que ver sino miraros?... y en esta fee meresco desearos (epistola) (6 octavas): 76r-77r. (Silvestre, ff. $368 \mathrm{v}-369 \mathrm{v}$, con sólo 5 octavas).

117. Luchan Amor e Ynterés, / y a tres yva la vencida, / y dio Amor tan gran caýda / que no osa luchar después. // 1) Luchan Ynterés y Amor, 2) Aunque Amor todo lo puede, 3) E1 Ynterés es gigante, 4) Las fuerças de Amor consisten: 51r.

118. Luz que me alunbra y me guía, / del valor, lustre y exenplo... si vuestra merçed quisiere (epistola) (15 coplas de pie quebrado: ABBA cCDDC eEFFE g...) : 104r-105r.

119. Llegado é a saber, mas con mi daño, / hasta quánto se estiende el mal de ausencia... tras vn largo esperar, desconfiança (soneto): 4v.

120. -Magdalena, ¿quies me bien? / -Dios mío, sabéislo vos. / -Magdalena, ¿cómo a quién? / -Como a rredemptor y Dios. // 1) Dulçe sierua, no dirás, 2) No dirás como a tus ojos, 3) Di como a tu coraçón, 4) ¿Como a quién me as de querer...? (coplas de María Magdalena): 69r. (Versión a lo divino de una letra, con glosa diferente, que está en Canc. Oxford, ff. 372r-373r: "Di, pastor, ¿quieres me bien?" También en Esteve Barba, f. 285r-v).

121. Marfida me dio vna rrosa. / ¿Quál sería, quál sería, / que tras esta niñería / me diese otra mejor cosa? // 1) Pareçe el darla señal, 2) Pero amor no suele ser: $24 \mathrm{v}$.

122. Más vale trocar / plazer con dolores / que estar sin amores. // I) $\mathrm{Si}$ es agradesçido, 2) EI que es más penado, 3) Es vida perdida: 130r. (De JuAn del Encina, Cancionero, Burgos, 1505, f. 75; reproducida por BöHL DE FABER, t. 1, p. 294. Faltan dos estrofas en nuestra versión. Otra versión trunca en Canc. Classense, f. 84v: "Mejor es trocar..."). 
123. Mira, no te cases, / pulida zagala, / mira lo que hazes, / así Dios te vala. /( 1) Si quieres contento, 2) Si te quies casar, 3) El lustre hermoso: $105 \mathrm{v}$.

124. Montaña seca, nublosa, / llena de piedras y rriscos... en paz y graçia las peras (contrarrespuesta de Juan de Alcalá a Jorge de Montemayor) (12 coplas reales) : 57v-58v. (Cf. núms. 125, 203 y 209. Estos poemas fueron editados, a base de dos mss., por José LÓPEZ DE TORO en "E1 poeta sevillano Juan de Alcalá", $A H, 14$, 1951, núm. 45, pp. 9-28).

125. Monte fértil Iusitano, / donde se crían laureles... pue[s] soy tuyo y tú cristiano (contradize Juan de Alcalá por carta) (6 coplas reales) : 56v s. (Cf. núms. 124, 203 y 209).

126. Muerta queda la melicia, / que yo la vide matar... ya diré por mí rrogarán: 132r-v (rromançe incluido en el núm. 37) . [Segunda mano].

127. Muy furioso andaua el moro / por el africano canpo... que saliese a demandallo (rromançe): 108v. (En Rom. historiado, pp. 160-161, donde empieza "Vente a mí el perro moro". Nuestra versión comienza en el v. 5 de la publicada).

128. Nada puede pretender / quien no tiene qué gastar, / pues no vale el bien querer, / sino el terçero qu'es dar. // 1) El honbre más avizado, 2) Hase hecho ya el amor, 3) El honbre que fuere pobre, 4) El honbre más mal tallado, 5) Las damas de conplimiento: 26r.

129. No ay por qué alguno se alabe / de discreto y auisado / si no ha sido enamorado, / pues ningún auiso cabe / donde el amor no ha llegado. // De las pasiones del alma, / la más noble y la mejor... (glosa): $106 \mathrm{v} s$.

130. No estés tan amodorrido, / agasájate, Paçqual; / que al pastor más dolorido / más se le aquillotra el mal. // l) Buelue en ti, dexa la pena, 2) Muéstrate más plazentero, 3) No te fatiguen antojos, 4) Pardiobre, si yo quisiera, 5) Mal podrá tener cuydado, 6) No sientes mi mal estraño, 7) Si mi mal de amor no fuera: $68 \mathrm{v} s$.

No hay, véase No ay.

131. No largo tienpo, no temor de oluido, / no la ynçierta esperança de no veros... que cresca el mal que a vuestra causa siento (soneto): $34 \mathrm{v}$.

132. No me mata mi tormento / siendo vos la que lo dais, / sino que me rrespondáis / qu'es fingido el sentimiento. // 1) No tengo en tanto la pena, 2) No muero con verme arder: 23r-v.

133. No miren my perdiçión / sino por quién me perdý, / y abrán enbidia de mý. // El contento de más gloria / que siente vn enamorado... (glosa): 72r-v. (La misma letra, con variantes ["No miréis mi perdimiento"], en Canc. Oxford, f. 323r; la glosa es diferente. El poema del Canc. Oxford también se halla en Paris 307, f. 229).

134. No soy mío, qual lo muestro, / ni vuestro, ni de los dos: / vuestro por no querer vos, / ni mio porque soy vuestro. // En la ley que Amor á dado / más estrecha y de verdad... (glosa): 43r-v. (La letra en Cartapacios, p. 44, y en Pedro de Padilla, Églogas espirituales, Sevilla, 1582, f. 124r).

135. No tomes, Juana, contento / con mi pena y mi cuydado; / mira que juega al trocado / la Fortuna en vn momento. // 1) Mira que jamás amor, 2) En extremo te contenta, 3) Gustas de dar disfabor, 4) Escarmienta, pues, zagala: 103r.

136. No uiéramos el rrostro al Padre eterno / alegre, ni en el suelo al Hijo amado... que en la siençia de Dios está la suma (6 octavas en loor 
de Nuestra Señora): 88r-89r. (¿De Francisco de Aldana?: véase Elias L. Rivers, "A new manuscript of a poem hitherto attributed to Fray Luis de León", $H R, 20,1952,159-158$ ) .

*137. Ojos, dezíselo vos / con mirar, / pues tan bien sabéis hablar. // Cresçe tanto la pasión / que mi ser y virtud mengua... (glosa): 12v-13v.

138. Ojos, dezíselo vos... // Pues avía causa, muero, / sin auer quien lo resista... (glosa): 19r. (La letra y la glosa en Padrlla, Thesoro, ff. $416 \mathrm{v}-417 \mathrm{r})$.

139. Ojos míos, ¿qué miráis? / Aquéste es el lugar donde os rrendistes... te llora el coraçón por más ausente (5 liras): $74 \mathrm{v} s$.

*140. Ojos negros, quando os vy, / vy todo mi bien y gloria; / no saldréis de mi memoria / mientras el alma esté en mý. // El brio, gloria, y contento, / la vista, ser y rrazón... (glosa): 6r-7r. (La letra y la glosa en Flor, p. 251).

*141. Oluida, Bras, a Costança, / líbrate de su cadena; / no fíes en esperança, / que no ay esperança buena. // No me da pena tu muerte, / que al fin fin tiene de ser... (glosa): 13v-14v. [El ay del v. 4 fue cambiado en da por otra mano].

142. ¡O manos poderosas de matarme! / y qué manos me diera de miraros... y que otro bien Amor no me otorgara (soneto a las manos de vna dama): 77r-v. (Figueroa, p. 133).

143. Omnipotente Dios en quien consiste / el rreparo de todo lo criado... que juntas te conoçen y te siguen (soneto): $117 \mathrm{v} s$.

144. ¡O qué rrefrán se an tomado / las monjas de poco acá: / primo acá, primo acullá! // 1) En enpesando a parlar, 2) Esta rrelijioza grey, 3) Es tanta su parlería, 4) An puesto vn cartel muy loco: $134 \mathrm{v} s$. [Segunda mano].

145. Oy ha nasido en el suelo / la que pudo en sí traer / el que en la tierra y el çielo / hera imposible caber. // 1) Sepan todos que es nasçida, 2) Vna vara naserá, 3) Jesu Christo soberano, 4) En thesorera del cielo... (de Nuestra Señora): 71r.

* 146. Pastora que en cayado / trae rretratado el pastor, / vencida la tiene amor, / lástima tengo al ganado. // Como ante vuestra hermosura! poner otra es desacato... (glosa): 49r-v.

*147. Pastores, herido vengo / de vn mal que no tiene cura; / álo de sanar ventura, / pero yo jamás la tengo. // Quien me aconsejó, cuytado, / siendo yo vn sinple pastor... (glosa): 54r-v. (La letra y la glosa en ZaRCo, p. 444).

148. Pique y rrepique y capote / auéis de llevar de vn zote. // 1) Muy rruyn lançe auéis echado, 2) No me os curéis de escusar, 3) Ordinariamente andáis, 4) No me lo podéis negar: 53r. [Intercalada en una ensalada, núm. 191].

149. - ¿Por qué no esperas, Ana? - Tengo miedo. / - ¿De qué, señora mía?... pues no meresçe silla, échenle alvarda (coloquio) (6 estrofas aliradas AbbACC) : 83r-84r. (En Canc. Juromenha, f. 2, y en Canc. serv., f. $228 \mathrm{r}-\mathrm{v})$.

150. - ¿Por quién lloras, pastor? -Porque é partido... - ¿De quién? -De la pastora más querida... que me será mayor contentamiento (so. neto): $77 \mathrm{v}$.

151. - ¿Por quién suspiras, zagal? / -Por vos, pulida pastora. / -Mentira es ésa, y qué tal. / -Verdad os digo, señora. // Con tanta fuerza y poder / muestras tu poder $[s i c]$... (glosa): 46r-v. (Letra parecida a otra 
del Canc. sev., f. 71r: "-¿¿A quién amas, di, zagal? / - A ti, pulida pastora. / -Lisonja es ésa, Pascual. / -Verdad te digo, señora").

152. - ¿Por quién suspiras, zagal?.. /// 1) ¿Por quién te aflige el deseo...?: $69 \mathrm{v}$.

153. Por vna gran espesura / que junto a Pariz auía ... que del paladín traýa (rromançe): $114 \mathrm{r}$.

154. Por vn verde prado / de frescas sonbras lleno y de mill flores... en verse avsente de su ninpha hermosa (9 sextetos-lira, con hexasílabos en vez de heptasílabos) : 115r-116r. (Canc. sev., ff. 195r-196r; Esteve. BARBA, ff. $247 \mathrm{v}-248 \mathrm{v}$ ).

155. Preso estaua el primer honbre, / que Dios le mandó prender... a Dios quesiste offender (rromançe): 114v.

156. Presumes de muy arquero, / ciego Amor, por alabarte; / lo más haze el dinero, / y el dïablo por su parte. // 1) De ese tu arco y aljaua... de que tú sueles preciarte, 2) Presumes de auer vençido... que tu arco en toda parte, 3) Tú lo que puedes hazer... que tú sueles aplicarte, 4) Es engaño de amadores... y el dïablo por su parte: 98r-v.

157. -Pues Menga te da tormento, / dexa, zagal, de querella. / -Nunca Dios me dé contento / si yo lo tengo sin ella. // 1) Zagal, sepulta en oluido, 2) Quien sirue sin esperar, 3) Viendo que Menga te oluida, 4) Tú estás loco o yo no entiendo: 101v $s$.

158. Pues que a todos los que os miran / os mostráis ser amadora, / tomá vna higa, señora. // 1) Menester á procurar, 2) Si days fabor al yndigno, 3) $\mathrm{Si}$ a los tristes amadores: $68 \mathrm{v} s$.

*159. Puesto ya el pie en el estribo, / con las ansias de la muerte, / señora, aquésta te escriuo; / pues partir no puedo viuo, / quanto más tornas [sic] a verte. // Puse mi amor verdadero / en una dama qu'espera... (glosa): 17v s. (La letra y la glosa en Flor, p. 258).

160. Pues tuue coraçón para partirme / tanpoco ha de faltar para matarme... pues vine yo sin vos, que sois mi vida (soneto): $1 r-v$. De oy más si por traidor fuere acusado / no ay rrespuesta que dar que satisfaga... (glosa del mismo soneto, en octavas): 1v-4r. (El soneto está también en Paris 373, f. 128v).

161. Qalquiera que [a] Amor siguiere / ha de sentir gloria y pena: / como goza el bien que ordena, / sufra el pesar que viniere. // 1) Al triste que Amor catiua: 46v s. (ANTONIO DE VIllegas, Inventario, 1565; reproducida por BöHL DE FABER, t. 2, p. 242. También Canc. Oxford, f. $369 \mathrm{r}$ ).

162. Quando bueluo a mirar el dulçe nido / del águila rreal y su morada... bien pueden ya contarme con los muertos (soneto): $41 \mathrm{v}$.

163. Quando Natura os hizo, ninpha mía, / la más bella de todas las más bellas... con la pena que todos le causaron (soneto): $118 \mathrm{v}$.

*164. Quando quiere Menga a Bras, / huye desdeñosa Menga; / nunca veréis que convenga / fortuna y amor jamás. // 1) Bras que por Menga se muere, 2) Si la fortuna de verla, 3) Amor en el vno ardiendo, 4) de que Bras tormento sienta, 5) Con los ojos de agua llenos: 95 v.

165. Quando quiso mostrar Naturaleza / de sus extremos todos los más bellos... bastaua darnos luz sin todas ellas (soneto): $118 \mathrm{r}-\mathrm{v}$.

166. -¿Qué cosa son los celos? - Mal rrauioso. / ¿ ¿De qué naçen o vienen? -De temores... y quien le trae ansŷ̀ su fantasía (soneto): 40r-v. (Atribuido al Licenciado Dueñas en Flores, f. $235 \mathrm{v}$ s.).

167. ¿Qué harán dos que Amor halla / heridos de vna çentella? / Ella de 
vergüença calla, / y él calla de temor della. // 1) ¿Qué harán dos coraçones...?, 2) E1 vno al otro se mira, 3) Ofréscense los despojos, 4) Él temeroso comiença, 5) Él procura que lo entienda: 50r-v. (Es de Padilla, Thesoro, f. $213 \mathrm{v}$ s.; también Canc. sev., f. $235 \mathrm{v}, \mathrm{y}$ Canc. Classense, f. $75 \mathrm{v}$, éste con desarrollo diferente).

168. ¿Qué haze acá, muger mía, / el cura, que no es de día? // 1) ¿Qué enfermedad os a dado?, 2) Aunque me llame conpadre, 3) Quando fuera menester, 4) Era esto el madrugarme: 53r. [Intercalada en una ensalada, núm. 191].

169. -¿Qué hazes, buen amigo? -Suspirando. / - Tu dama, ¿adónde está? -Do ella quiere... que no he uisto carbón más negro que ellos (soneto): $40 \mathrm{v}$.

170. [Quien dize que el ausençia causa oluido...] Amor y su contrario / están en vn subjeto $\mathrm{y}$ vn sentido... (glosa de "Quien dize que el ausencia causa oluido") (8 liras) : 37r-38r. (El soneto glosado es de Junn Boscán, Obras poéticas, ed. M. de Riquer, t. 1, Barcelona, 1957, p. 182. Hay otra glosa en liras en Canc. sey., ff. $204 \mathrm{v}$ s.).

171. Quien ha hallado el Criador / de la tierra, mar, y cielo... para que jamás no muera (coplas de pie quebrado, ABBcCDDeEFFgGHH...): 71r-v.

172. Quien llamó al partir "partir" / rreçibió engaño a la clara: / harto mejor acertara / si lo llamara "morir", / que al morir "partir" bastara. // Duele tanto la partida / de dos que se quieren bien... (glosa): $70 \mathrm{v} \mathrm{s.}$

173. Quien llamó al partir "partir" / rrecibió engaño a la clara; / si le llamara "morir" / harto mejor açertara. // Señora de mi querida / como sienpre a tu obediençia... (glosa): $26 \mathrm{v} s$.

*174. Quien no estuuiere en presençia / no tenga fee en confiança, / que son oluido y mudança / las condiçiones de ausençia. // Pierda el ausente cuydado / 'si se detuuiere vn día... (glosa): 106r-v. (La letra es la conocida de Jorge Manrique).

175 ¿Quién os engañó, señor, / en aceptar desafío?... y seruiros del pellejo (coplas de don Diego de Mendoça contra don Francisco de Fonseca) (17 coplas reales y una quintilla final): 20r-21v. (Publicada por Gallardo, t. 1. núm. 85, y en Poesias de Baltasar del Alcázar, Madrid, 1878, pp. 157-165 [falta en la ed. de Madrid, 1910, sin explicación]. También se halla anónima en Hispanic Soc., núm. LXVI, f. $12 b$, y en Cartapacios, p. 45, atribuida a D. J. D.) .

176. [Quien pierde por vos la uida...]. (Véase núm. 177). // En lo más dificultoso / suele prouarse el dolor... (glosa): 109v s.

177. Quien pierde por vos la uida / no tiene más que perder, / sino que pierda el plazer / de verla tan bien perdida. // Quien pocas cosas procura, / avnque la venga a alcançar... (glosa): 109r-v.

178. ¿Quién podrá no amaros, / si el Amor, señora, / por enamoraros, / de vos se enamora? // 1) Voy al ciego dios, 2) Mira mi ventura, 3) ¿Qué rremedio ansí...?, 4) Pues al ciego dios, 5) Si a mi amor fiel: $47 \mathrm{v}$ s. (La letra en SiLvestre, f. 109v. Hay versión contrahecha en LóPEz DE Úbed, f. $20 \mathrm{v}$, con el mismo primer verso).

179. ¿Quién podrá oluidaros, / pues Amor, sin veros, / gusta de quereros / sin enamoraros? // 1) Si sola la fama, 2) El que nunca os vio, 3) Y aunque más le ofende: 22v.

180. Quien tiene pasiençia / para estar ausente, / muy de burlas siente / los males de ausençia. // 1) El que está apartado, 2) El que noche y día: $51 \mathrm{r}-\mathrm{v}$. 
181. Qüitado, que en vn punto lloro y rrío / espero, quiero, temo y aborresco... tales son los extremos en que biuo (soneto): 34r. (Poema atribuido a Camões que se halla sin tal atribución en "136 sonnets", Canc. Oxford, Flores, Canc. Juromenha, etc. Véase JosePH G. FuCILlA, Estudios sobre el petrarquismo en España, Madrid, 1960, pp. 94-95) .

182. Riberas del Danubio, fresco rrio, / sus mansas ovejuelas rrepastando... sus dolorosas ansias aliuiaua (soneto): $118 \mathrm{v} \mathrm{s.}$

183. Riberas de vn hondo rrío / do muy clara agua corría... adonde biuir solía (rromançe): 100v (Hay otra versión en Timoneda, Rosa de amores, f. 5 lr-v, con muchas variantes).

184. Rompiendo el ayre junto al alto çielo / Dédalo con su hijo caminaua... no fue sino de auer tanto subido (soneto): 4lr-v. (En Canc. Riccardiano I, f. 187r, y en Paris 373, f. 219).

185. Ruego a Dios en quien adoro, / si castigo en mí á de hazer, / muera yo en cuernos de vn toro / y no puestos por muger. // ¿Quién gusta de ser ligado / con muger, mar de mudança?... (glosa): $10 \mathrm{v}-11 \mathrm{v}$.

186. Salgan ardiente[s] suspiros, / el ansia del coraçón / publicando... dedicada (lamentaçión) (9 coplas de pie quebrado): $67 \mathrm{r}-68 \mathrm{r}$.

*187. Salgan las palabras mías / sangrientas del coraçón, / entonadas a aquel son / que cantaua Hieremías / en el monte de Sión. // Muerte que pones espanto, / trabajosa, acerua y dura... (glosa): 59r-v.

*188. Salgan las palabras mías... // Por nueştra naturaleza / a poco bien ynclinada... (glosa): 60r-v.

189. Salgan las palabras mías / sangrientas del corasón... con alguna consolación (carta que un soldado enbió del castillo de Enberes a in gentilhonbre) ( 25 quintillas precedidas de una carta en prosa: $133 \mathrm{r}-134 \mathrm{v}$. [Segunda mano. Incorpora versos de poemas divulgados de la época].

190 Salía rrepastando / al tienpo que ya Phebo parescía... llamándole mill vezes atrevido (11 sextetos-lira): 116-117v. (Ocho estrofas en Padilla, Thesoro, ff. 228r-229v).

191. Satanás, que no rreposa, / ni ay puerta por do no pase... que los hizieron amigos (ensalada de Padilla): 52r-54r. (También se halla en París 372, f. 16, con el título coplas de Juan Garcia. Cf. núms. $102,113,148$ y 168 ).

192. Señora Ynés, que no soy perulero, / ni quiero ser tan vuestro enamorado... porque es darme la vnción pedirme nada (soneto): $33 \mathrm{v} s$.

193. Señora Leonor, estoy corrido / de qu'entendáis que andaua tan picado... más me quiero yr a pie que por la posta (soneto): $28 \mathrm{v} s$. (También en "136 sonnets", p. 367: "Señora Catalina, estoy...").

194. Señora mía, el grande amor que os tengo, / con vn firme deseo de agradaros... que yo por nesçio quiero ya dexaros (quistión entre vna dama y on galán) (27 tercetos): $81 \mathrm{v}-83 \mathrm{r}$.

195. Señora, vuestros cabellos, / con que al mismo Amor matáys, / si de lexos los mostráis, / ¿por qué los llamáis "cab'ellos"? // 1) Si el Amor çiego se ofende, 2) Cosa de tanta belleza, 3) El coraçón que los vido, 4) Rayos de luz esparzidos: 104r.

*196. Señora, vuestros cabellos / de oro son, / y de azero el coraçón. // Queriendo hazer Amor / diferençia en los amores... (glosa): 27v. (La glosa es de FigueroA, p. 229).

*197. Señora, vuestros cabellos / de oro son, / y de azero el coraçón / que 
no se muere por ellos. // Vuestra esmerada belleza, / mirada parte por parte... (glosa): $107 \mathrm{v} s$.

198. Señora, yo me despido / de vos y de mi querer, / y asiento con el oluido / por lo que podría perder / más que por lo que é perdido. // Rendido y preso me vy / y sujeto a mi deseo... (glosa): $7 \mathrm{r}-8 \mathrm{r}$. (La letra está en el romancero de la Bibl. Brancacciana: véase $R H i$, 65,1925, p. 386).

199. Si el amor que me mostráis / lo mudáys quando queréis, / no es amor el que tenéis. // 1) Amor que sufre mudança, 2) De quequiera gentil dama, 3) $\mathrm{Si}$ me dais por desengaño: 107r-v.

200. Si el galán es auisado / y la dama es pica de loca, / andan las manos y calle la boca. // 1) Regla es ésta aueriguada, 2) En auiendo coyuntura, 3) El que perdiere ocasión: 51v s. (También en Flor, p. 24l).

201. Si el más alto pensamiento / da más pena al coraçón, / el que tiene esta pasión, / ¿cómo biuirá contento? // 1) Quien más encunbrado buela, 2) Ciertos los daños están: 44v.

*202. Si el suspiro da pasión / del coraçón a la boca, / ¿qué hará si torna y toca / de la boca al coraçón? // Quando el alma está afligida / y en su pena medio no ay... (glosa): $11 \mathrm{v}-12 \mathrm{v}$.

203. Siendo ya el tienpo llegado / en que Cristo determina... otro en cruz por la mañana (carta de Juan de Alcala a Jorge de Montemayor sobre el herror que hizo en vnas coplas de la Pasión en su cancionero, que son éstas:...) (2 coplas reales): 56r-v. (E1 verso citado encabeza la selección de Montemayor que critica Juan de Alcalá; el poema de Alcalá empieza en el f. 56v, "Monte fértil lusitano": cf. núms. 124, 125 y 209).

*204. ¡Si mi "fue" tornase a "es" / sin esperar más "será", / o si fuese el tienpo ya / de lo'que será después! // Sienpre tengo en mi pasiençia / el tormento o la vitoria... (glosa): $16 \mathrm{v} s$.

205. Si no es desamor / no ay mal que lastime. / ¡Ay coraçón triste!, / ¿cómo biues?, dime. // 1) Vine a ser amado, 2) La suerte dichosa, 3) Quitóme el contento: 127v s. (También en Canc. sev., f. 248v: "Si no ay desamor...").

206 Si yo, señora mía, conoçiera, / antes que en vuestro lecho me acostara... durmiéronse mis ojos justamente (soneto): $28 \mathrm{v}$.

Si..., véase también Sy...

207. Sobre la profunda arena / Medoro trizte yazía... de Françia, España y Vngría (rromançe): 128r-v. (Rom. historiado, pp. 158-159. Véase Chevalier, pp. 252-253. El texto publicado empieza "Sobre la desierta arena").

208. Socorred con agua al fuego, / ojos, apriesa, llorando, / que se está el alma abrasando. // Saliendo vna noche obscura / antes de las diez vn poco... (glosa): 128v s. (Pliegos, núm. 1100, p. 592, contiene la letra, ¿y la glosa? Se desconoce el paradero de este pliego de $\mathbf{1 5 7 6 .}$ La letra, con glosa diferente, en Padilla, Thesoro, f. 240v. Versión a lo divino en López DE ÚBEDA, f. 143v: "Socorred, Pastor, al fuego...").

209. Son palabras de loor / notarme de mal cristiano... son los tres que en vno digo (rrespuesta de Montemayor a Alcalá) (6 coplas reales): $57 \mathrm{r}$-v. (Cf. núms. 124, 125 y 203).

210. Soñé, señora, que estaua / vuestro amor sienpre en vn ser, / y con el 
grande plazer / desperté, y vi que soñaua. // Como sienpre el pensamiento / está donde esté mi dueño... (glosa): 27r.

*211. Soy hermosa y auisada, / tengo gracias más de mill; / llámanme Gira Giralda, / hija de Giraldo Gil. // Con admirable destreza, / çielo y tierra y conpañía... (glosa): 108r-v.

212. Soy la misma luz del día, / soy consuelo para vos; / llámanme Virgen María, / esposa y madre de Dios. // Yo soy la madre del rrey...: 99r. (Versión a lo divino del núm. 2I1).

213. Suspiros, de do salís / no salgáys, / que se ofenden donde vais. // 1) No salgáis a presentaros, 2) El fuego qu'está encerrado, 3) No uais a dezir que muero: $23 \mathrm{r}$.

214. Suspiros, yd do salís / y dezid mi muerte çierto, / porque quando allá lleguéis / podréis dezir que soy muerto. // 1) Ha sentido el dolor tanto, 2) No tengáis a la contienda, 3) Pues soys el vltimo aliento, 4) Por tanto, antes que mi pecho: $99 \mathrm{v} s$.

215. Sy estoy quanto es posible a vos rrendido, / ¿de qué sirue mostraros tan ayrada?, / qu'es dar a moro muerto gran lançada. // Sy veis que el alma mía sólo quiere / querer obedeçeros y agradaros... (glosa) (3 octavas reales): 79r-v. (La letra se halla en Pliegos, núm. 722, p. 432).

216. Sy os preguntaren, my uida, / si nos queremos los dos, / dezý que no me conoçéis, / y mirá / no me maten a mŷ por vos. // 1) El ver. dadero querer, 2) La muerte no temería, 3) Si mi madre os encontrare: $54 \mathrm{r}$.

Sy..., véase también Si...

217. Tan cansado está ya my sufrimiento / que a mí mismo no puedo ya sufrirme... pues es mayor vitoria rremediarme $(8$ octavas rrimas de Silvestre): $84 \mathrm{r}-85 \mathrm{r}$. (A pesar de la atribución, el poema es de PADILlA, Thesoro, ff. 199r-200v).

218. Ten, carillo, algún saber, / no andes tan enbobesido; / buelue en ti, que vas perdido; / no te acabes de perder. // 1) Tu fee tan enamorada, 2) Viendo la desygualdad, 3) Dexa ya aquesa locura, 4) Claro entiendo que soy loco, 5) Todos los males y daños, 6) En esto hago ventaja: $65 \mathrm{v} s$.

219. -Ten qüenta con tu ganado, / Toriuio, que va perdido. / -No es mucho auerlo oluidado / quien se á puesto assy [sic] en oluido. // 1) Buelue en ti, zagal, ten cuenta, 2) Nunca en mi uida pensé: $62 \mathrm{v}$.

220. -Traydor, jno me dezías que me amauas? / -Sí dixe, y lo diré toda my vida... tú las sigues y alcanças valedoras (soneto): $74 \mathrm{r}$.

221. Tu carta recibý, que no deviera, / pues quando de leerla vue acabado... aquý verán mis penas postrimeras (rrespuesta) (33 tercetos): 31v-33v. (Respuesta al núm. 29. También en Flores, ff. 97v-100r). Un..., véase Vn...

Uno..., véase Vno...

222. Ved en lo que he dado, / que es cosa donosa: / ando enamorado / de vna melidrosa. // I) Es cosa de rrisa, 2) No es Venus tan linda, 3) De sólo cortar, 4) Cierto es cosa loca, 5) Soy testigo dello, 6) Es grande donayre, 7) Y quando se ofreçe, 8) Vna noche quando: $129 \mathrm{v} s$.

*223. Ve do vas, mi pensamiento; / ymbidia tengo de ty, / pues verás el bien que vy / sin sentir el mal que siento. // Agradable conpañía / haze la ymaginaçión... (glosa) [sólo se glosan los tres primeros versos]: 27v s. (Canc. sev., f. 207r, TIMonedA, Sarao de amor, Va- 
lencia, 1561 , f. $36 \mathrm{v}$, y Canc. Classense, f. $11 \mathrm{v}$, contienen la letra y la glosa).

224. Véngome a buscar acá, / si acaso saben de mŷ, / que dizen que me perdý / do vuestra merced está. // 1) Es tanta mi perdiçión, 2) No os pido que me soltéis, 3) Yo no pongo duda en ello, 4) Ageno de mí por vos, 5) Sólo lo quiero saber, 6) $Y$ no es mucho que digáis: 110v. (La letra es de Gregorio Silvestre, Poesias, ed. A. Marín Ocete, Granada, 1938, p. 48) .

225. Venida soy, Señor, considerada / vuestra grandeza y la miseria nuestra... y que es lo que de mý más os agrada (enfados a la duquesa de Alcalá) (16 tercetos): 79v-80v. (De Baltasar del Alcázar: véanse sus Poesias, Madrid, 1910, p. 159. También en Flores, ff. 12-13).

226. Vestirme quiero de luto, / señores, por algún dia, / porque es puto y más que puto / aquel que de putas fía. // I) Fiar de ninguna puta, 2) la muger que alça las faldas, 3) No se contentan con vno, 4) La que dixere que siente, 5) Ninguno esté confiado, 6) Ay algunos majaderos: $58 \mathrm{v} s$.

227. Vida y muerte no me quieren / aunque biua, ni aunque muera. / ¿Quién hallaré que me quiera? // 1) Sy la vida no me ama, 2) Si quiero biuir no biuo, 3) Por ti el biuir me á dexado: 23v.

*228. Vide a Ju[a]na estar lavando / en el rrío y sin çapatas, / y díxele suspirando: / "Di, Juana, ¿por qué me matas?" // En vn lugar sonoroso / del Tajo fértil sonbrio... (glosa): 49v. (La letra y la glosa en Juan Timoneda, Cancioneros, ed. A. Rodriguez-Moñino, Valencia, 1951: Guisadillo de amor, ff. 6v-7v. También en Flor, p. 175).

229. Viendo la gran potencia y valentía / que tiene en las mugeres el ducado... sino con el doblón de oro muy fino (4 otauas de amor $e$ ynterés): $39 \mathrm{r}-\mathrm{v}$.

Vive, véase Biue.

230. Vn marquesote brauo y entonado / vn barbero llamó que l'afeytase... y en todo quanto en ella auéis hecho (soneto): 4lr. ("136 sonnets", p. 353).

231. Vno es vno, / y no lo entiende ninguno; / y dos son dos, / mas que no lo entendéis vos; / y tres son tres: / apostá que no lo entendéis. // Es vna essençia / sagrada sin distinçión... y tres son tres (glosa): 98v. (La letra en Hispanic Soc., núm. LIII, f. 59v, y en "Tres cancs." cit. en Ábaco, 2, p. 262).

232. Vuestros cabellos, Leonor, / por mi mal mis ojos vieron, / pues de muerte me hirieron / cabellos y vos y amor. // I) Pues os dio naturaleza, 2) Amor y vuestra hermosura, 3) Amor siruió de terçero: 22r-v. (Versión a lo divino en Pliegos, núm. 342, p. 267: "Estos cabellos, Señor...").

233. Ya no más amor de aldea; / téngalo quien lo desea. // 1) No más amor de aldeana, 2) Si de amores la tratáis, 3) Quando os estáis desaziendo, 4) Presumen tanto de honradas, 5) No ay entenderse con ellas, 6) No ay dezirles "peno y muero", 7) Andaréisos todo el año, 8) Más quiero vn solo fabor: $96 \mathrm{v} s$.

234. Yo me lo sé el porqué, avnque no lo digo. // 1) De oy más me vestiré de vn triste luto, 2) Tendré la gente aborresida tanto, 3) Mi exerçiçio será en aquel deçierto, 4) Lo poco que la vida me durare, 5) Publicaré mi triste sentimiento, 6) Quando hago mi qüenta más estrecha (glosa) (6 octavas): 42r-43r. (Zarco, p. 420, y Canc. sev., f. 55r-v. También ms. 12-26-8/D 199 de la Real Academia de la 
Historia, f. 65: cf. $B R A E, 12,1925$, pp. 521-522. El mote solo en Padilla, Thesoro, f. 299v).

235. -Yo no quiero que me quieras; / muda, zagal, tu querer. / -Pues yo te quiero querer / aunque tú más mal me quieras. // 1) Tu fuego nunca me quema, 2) Yo buscaré nueuos modos, 3) Yo me bolueré huyendo: 95v s. (La letra en Paris 314, f. 213v = LAYNEZ, p. 432: "Ya no quiero...").

236. Yo no sé en qué se rrecrea / el que tiene la muger fea. // 1) Para ser su afiçionado, 2) Siendo fea es muy celoza, 3) Las mudas rruuias cerillas: $25 \mathrm{v}$.

237. Yo sin mý sin vos acá, / vos allá sin vos y mý: / si es posible ser ansý / nuestro ser, cadónde está?, / pues que no está allá ni aquý. // La mayor admiraçión / a qualquier juizio perfeto... (glosa): 44r-v.

238. -Zagala [sic] que vas por la sierra, / ¿cómo te ua con amar? / -Antes me trague la tierra / que me buelua a enamorar. // 1) $\mathrm{Di}$, zagal, cómo te ha ydo, 2) ¿Dónde está el contentamiento...?, 3) ¿Dó está aquella confiança...?: $111 \mathrm{r}$.

239. Zagal, si vas al aldea / y vieres a mi zagala, / dirásle que acá no ay gala / que como la suya sea. // 1) Sy fueres tan venturoso, 2) Quando salgo rrepastando, 3) Dirásle que my ganado, 4) Dile que todo es escoria: 97r-v.

\section{LOS INTERESES CREADOS: NOTA ESTILISTICA}

En el prólogo a Los intereses creados, Benavente disfraza, bajo la fórmula de rigor para tales presentaciones teatrales al público, una predominante preocupación por el estilo. Hace hincapié en el poder que tiene el poeta de transformar en poesía materiales de por sí nada poéticos. Como ejemplo de ello, dice que la farsa pasa de la plaza al palacio, donde "ilustró después su plebeyo origen con noble ejecutoria: Lope de Rueda, Shakespeare, Molière, como enamorados príncipes de cuento de hadas, elevaron a Cenicienta al más alto trono de la Poesía y del Arte". Por otra parte, Benavente se dirige a "un culto auditorio de estos tiempos", es decir, al oyente o lector dotado de una preparación estéticolingüística adecuada para comprender y apreciar las conversaciones de lengua diaria en lengua literaria, que él crea con su manejo individual de la lengua. De hecho, nada tarda en deleitar a este "culto auditorio", puesto que en el título mismo de Los intereses creados nos brinda un franco testimonio de sus dotes como artista de la palabra.

Al ofrecernos esta prueba sobresaliente de su talento, Benavente pone de manifiesto tanto las semejanzas entre lengua diaria y lengua literaria como las diferencias que separan a estos dos usos, distinguiendo su "noble ejecutoria" de su plebeyo origen. El hecho de que la frase los intereses creados tenga un uso, ya sea diario, ya literario, indica sencillamente que para ambos usos se acude a la misma lengua o sistema de signos verbales: al mismo léxico y a la misma gramática. Su empleo diario o casual revela, a primer golpe de vista, que los intereses creados es una rutina lingüística, una fórmula petrificada, una frase hecha que 